\title{
Editorial
}

\section{Impact Factor and SASE's annual prize}

In 2012, Socio-Economic Review received its first Impact Factor: we are proud that SER attained a strong 1.78. It ranks $11^{\text {th }}$ in Political Science and $15^{\text {th }}$ in Sociology. We thank all those who have contributed to the success of SER, and ask for your continuing support to make it flourish in future years as well.

It is also a great pleasure to announce that SASE's prize for the best article published in 2011 has been awarded to Daniel Oesch and Jorge Rodríguez Menés for their paper 'Upgrading or polarization? Occupational change in Britain, Germany, Spain and Switzerland, 1990-2008' (SER 2011, Issue 3). The prize of 1,000 dollars was presented at the SASE 2012 Annual Meeting in Cambridge, MA. Congratulations!

Wolfgang Streeck and Juergen Feick (Chief Editor and Managing Editor, 2006-2012) 